\title{
Don't Squeeze the Charmin' - ethical handling of information in the digital age
}

\section{S. Berner \\ sberner@ecognus.com}

I am not sure if any of the readers remember the problem with the Palm Beach vote during the 2001 US presidential elections. The Democrats, then represented by the Gore-Lieberman ticket, had their voting ballot designed in such a way that confused thousands of people voting for them into voting also for Pat Buchanan, of the Reform Party. The information explaining that voters who punched both holes on the ballot instead of just one were voting for Buchanan was on the following page - and people who do not have a reason to suspect any foul play, never turned the page over to find out about the second nominee.

This lead to the sadly ironic situation in which over 20000 voters, mostly of Jewish background, voted for Buchanan, whom they perceive as extremely anti-Semitic. Was the ballot, itself an information object, construed in a manner that was in some way unethical, since it caused misinformation during one of democracy's most important processes?

Asking questions about ethics is seldom - if ever - a comfortable undertaking. Philosophers usually ask uncomfortable questions and as such are usually considered either dangerous or spoil-sports. The rest of humanity usually does not feel the need to do so and often ignore such questions and their answers, often because they entail reflection. When you couple the short attention span that the 21st century seems to suffer from with changes that occur at the speed of light, even the questions may get overlooked as humanity grapples with the onslaught of ever newer, ever faster change by creating 'rules' instead of pondering the fundamental principles that have led to such rules. Our life seems to have developed into a sort of 'till you drop' attitude that leaves us with precious little time for any deep and meaningful reflections.

It would be preposterous of me to try and reflect on anything as weighty as ethics of information handling in an editorial. Instead, I propose to drop in a few preliminary questions and hope that they may provide the basis for further thoughtful discussion.

Ethics - or moral philosophy - is defined as any system of moral principles. Moral principles are guidelines for action, not rules. Severson (1997) provides us with four principles of information ethics: (a) respect for intellectual property; (b) respect for privacy; (c) fair representation; and (d) doing no harm. Under these main four headings falls a whole spectrum of issues information scientists and users grapple with everyday: plagiarism, copyright, fair and responsible use, bias, interpretation of information, censorship, misinformation, privacy, access to information - to mention a few. Severson proposes a fourstep method for practicing principled information ethics, optimistically starting with 'Get the facts straight'. Oh, yes?

The Internet provides us with an endless spectrum of information ranging from facts, 
opinions, interpretations and representation to propaganda, GIGO and outright lying. Should we mention criminal activity here as well, since the Internet does not lack that either? The paper-based daily media are in no way better, defamation laws notwithstanding. Visual media seem to be putting infotainment over and above any form of factuality - the more outrageous the programme, the wider the possibility that it will be viewed, and thus the higher the ratings. The whole information provision industry is geared towards 'selling', not informing. Where is the knowledge we lost in information? And without having knowledge, can we have ethics?

Who will shoulder the responsibility for ensuring that the end-user receives 'ethical' information? Teachers? Information scientists? Librarians? Parents? The state? And if any of those put up their hands and volunteer for this arduous task - how can we ensure that their acts will in themselves be ethical, and that bias and censorship - both inherent in human nature - will not foil the attempts? One would assume that educators have the responsibility of developing critical thinking among their charges and teaching them how to apply these to the perusal of media, with particular attention paid to issues of accuracy, reliability and authority. But is it also the educators' duty to teach information ethics? At what stage? How? We live in an age where humanities are no longer important in school curriculums of the Americanized world - can information ethics be taught outside the relevant framework of general ethics, of philosophy? Will not doing that court the danger of rendering the whole exercise into a creation of 'do and don't' rules to be followed inflexibly without thinking. And if that be the case, will these rules not be flouted because - in this post-modernist, deconstructionist world of ours - 'rules are there to be broken'?

An article published in 2001, by School Libraries in Canada, enjoins teachers to teach students how to avoid plagiarism and create original information using creative thought. I find both sentences interesting because the premises propagated in them highlight another problem - whose ethics will win? In the West, intellectual property is sacrosanct and copyright protected by law. As strange as it may seem, to another culture the notion that someone can hold ANY information as theirs by right is anathema. According to the Muslim religious law, Shariah, ownership is confined only to tangible materials. Knowledge, in Islam, is not the property of an individual - maybe because 'knowledge' in that religious thought is sacred - and as such no one can prevent others from acquiring it. In the opinion of Muslim scholars, copyright can be applied only when it prevents others from making largescale commercial profit out of someone else's 'intellectual property'. Economic realities and exposure to Western beliefs are slowly forcing an increasing number of Muslim states to impose some form of copyright legislation, and find a religious ruling for it, but it runs against the grain.

The other issue highlighted by the article was the 'creation of original thought'. I will revert again to traditional Muslim countries, were knowledge is still extremely scholastic and where 'original thought' is not encouraged, while the act of copying (naql) and interpreting (tafseer) are. Textbooks in Arabic that have references and footnotes are a novelty. Is it right then to impose a set of ethics from one culture on another, even if they vary?

While we are on the subject of copyright and intellectual property, a different ethical question imposes itself. What about the right of humans to know? How does this right fit with the fact that most scientific knowledge resides in the wealthy West, which through the power of its copyright legislation can also manipulate the cost of this knowledge. Does it mean that it is ethical to prevent the zillions of impoverished inhabitants of the third world from obtaining knowledge, effectively banning them from ever attaining the kind of informed progress that would move them up the development curve? What about the patenting of vital pharmaceutical inventions that preclude the Third World countries from developing their own, cheaper, medication? In short, is the knowledge gap encouraged by 
ethics - incidentally the same ethics that preaches nonmaleficence?

Misinformation is often equated with outright untruth. But the issue is not always that straight forward. Is a human rights lawyer engaging in unethical misinformation when he manipulates factual information in his submission in such a way that it is not exactly incorrect, but not exactly correct either, because it will save the life of his client?

An interesting incident occurred to me a few months ago. A medical agency wanted a pamphlet on meningitis translated. A statement saying that 'lack of immunization could have serious consequences for the child' was translated by one linguist as 'not immunizing your child will have dangerous consequences'. When the translated text was back-translated into English, the agency was not happy. The translator explained that his community had to be 'threatened into taking action' and that a 'wishy-washy' term such as 'may have serious consequences' would mean that they did not have to take any action towards immunizing the child. The agency responded that although they were aware a child who was not immunized could die if he or she was infected, 'they could not be perceived as alarmist in the way they informed the community'. Who of the two was misinforming the end-user?

As difficult as certain aspects of misinformation may prove to be, informing the public is wrought with even higher risk. It is very difficult to inform without interpreting. Is interpreting information unethical? If it is, then it precludes the interpreter's right to freedom of opinion; if it is permissible to interpret information while educating others, then how can we avoid all kinds of bias in that interpretation? If a teenage girl walks into the reference section of a library and asks for information on abortion, is it ethical to provide information about the nearest counselling service or clinic, or should one say nothing and endanger the teenager's life? What if providing her with this kind of information is against every grain of what the information provider believes in (for example that pre-marital sex is a sin or that abortions are equivalent to murder)? Neutrality is an ethical stance - but neutrality can also mean shirking the burden of not doing harm by doing nothing.

None of the questions asked in this editorial are new. However, as the information landscape changes continually, it may be necessary to provide them with new answers. These answers, often awkward and uncomfortable, will not emerge at the speed of light. They will need reflection, study and hard work - we cannot, however, afford to ignore them and hope that everything will eventually sort itself out. We must develop an everyday habit of pondering them and trying to live the response our conscience provides.

\section{References}

Severson, R.J. 1997. The principles of information ethics. New York: ME Sharpe.

\section{What to read}

Froehlich, T.J. 1997. Survey and analysis of legal and ethical issues for library and information services, UNESCO Report for the International Federation of Library Associations. IFLA Professional Series. Munich: G.K. Saur.

Mason, R.O., Mason, F.M. and Culnan, M.J. 1995. Ethics of information management. Thousand Oaks (CA): Sage.

Mendina, T. and Britz, J.J. (eds) 2004. Information ethics in the electronic age: current issues in Africa and the world Jefferson (NC): McFarland.

Mintz, A.P. (ed) 1990. Information ethics: concerns for librarianship and the information 
industry. Jefferson, (NC) and London: McFarland.

Oz, E. 1994. Ethics for the information age: cases, business and educational technologies. London.

Spinello, R.A. 2003. Cyberethics: morality and law in cyberspace. Jones and Bartlett.

Zipkowitz, F. 1996. Professional ethics in librarianship: a real life casebook. Jefferson (NC) and London: McFarland.

\section{About the author}

Sam Berner (B.Ed., Dipl. LIS, Postgraduate Diploma in Information Management) is a principal of the company ECognus (Brisbane, Australia). She is a knowledge management consultant, assisting small to medium enterprises to benefit the most from their intellectual assets. ECognus also provides services in the area of tailored software applications and the digitization of business processes.

\section{Disclaimer}

Articles published in SAJIM are the opinions of the authors and do not necessarily reflect the opinion of the Editor, Board, Publisher, Webmaster or the Rand Afrikaans University. The user hereby waives any claim he/she/they may have or acquire against the publisher, its suppliers, licensees and sub licensees and indemnifies all said persons from any claims, lawsuits, proceedings, costs, special, incidental, consequential or indirect damages, including damages for loss of profits, loss of business or downtime arising out of or relating to the user's use of the Website.

ISSN 1560-683X

Published by InterWord Communications for Department of Information and Knowledge Management, University of Johannesburg 